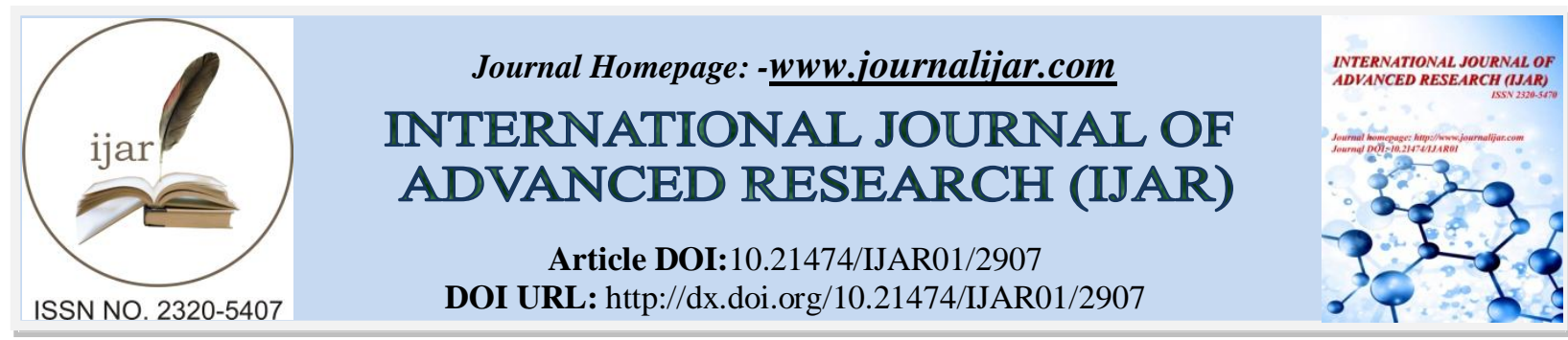

RESEARCH ARTICLE

\title{
EVALUATION OF KNOWLEDGE, ATTITUDE AND PRACTICE OFHIV/AIDS IN THE STUDENTS AT TAIBAH UNIVERSITY
}

Omar Aljohani, Abdel Rahman Ramadan and Abdulrahman Almadani.

\section{Manuscript Info}

Manuscript History

Received: 24 November 2016

Final Accepted: 25 December 2016

Published: January 2017

\begin{abstract}
Introduction:Acquired immunodeficiency syndrome (AIDS) caused by the human immunodeficiency virus (HIV) is a major health problem in many parts of the world, and is considered as a pandemic disease [1, 2].

Aim:To find out the knowledge, attitudes and Practice among Taibah university students towardHIV/AIDS.

Material and Method:A cross sectional analytic study using an online anonymous self-administered structured questionnaire was used to collect information, there were 484 respondents to the questionnaire from students of both genders from the various colleges

Results:From the total of 484 respondents there were 139 (28.7\%) males and $345(71.3 \%)$ females, The majority of the respondents 442(97.4\%) have heard About HIV/AIDS, the respondents shows an average level of KAP regarding HIV/AIDS, Positive attitudes towards HIV/AIDS were observed among 53.3\% of respondents, However $82.9 \%$ said they heard condoms.

Conclusion:It is recommended to start HIV/AIDS Prevention Programs at Taibah University giving attention to changing attitudes and practices among students...
\end{abstract}

Copy Right, IJAR, 2016,. All rights reserved.

\section{Introduction:-}

Acquired immunodeficiency syndrome (AIDS) caused by the human immunodeficiency virus (HIV) is a major health problem in many parts of the world, and is considered as a pandemic disease [1,2]

HIV/AIDS is one of the fastest-spreading epidemics in the world. There are 42 million people living with HIV/AIDS worldwide, and more than half of them are adolescents. [3]

Sexual contact remains the main mode of transmission of the disease worldwide followed by intravenous drug use and perinatal transmission [4]

HIV/AIDS, Its mode of transmission is known and is easily preventable, but because of the lack of knowledge and practices about HIV/AIDS in general population causes its rapid spread. So, this study was conducted to assess and compare the knowledge, attitude and practices about HIV/AIDS among the students at Taibah University[5] 


\section{Study objectives:-}

- To find out the knowledge, attitudes and Practice among Taibah university students toward HIV/AIDS.

- WE will share the resultsand try to contact with the responsible members in Taibah University to explain to them the results so they can take measures to increase the student awareness toward HIV/AIDS.

\section{Study Design:-}

A cross sectional analytic study using an online anonymous self-administered structured questionnaire was used to collect information using google form sent to the emails and cell phones of the students at Taibah University in ElMadinah El-Munawarah through the Deanship of Student affairs.

The sample size is using the Roasoft ${ }^{1}$ sample size calculator, based on the estimate that $50 \%$ of students may have enough knowledge on HIV/AIDS. Margin of error was set at 5\%, 95\% confidence, and an estimated 10\% drop out, our expected sample size is 415 students.

Data entry and analyses of results will be done using the Statistical Package for Social Sciences (SPSS) ver 21 for Windows software ${ }^{2 .}$ Descriptive statistics such as mean and standard deviation (SD) for continuous variables, and frequency and percentage for categorical variables will be determined. Inferential statistics will then be followed using parametric and non-parametric test for univariate analysis followed by multivariate analysis using logistic regression. The level of significance is set at $\mathrm{p}<0.05$.

\section{Sample size:-}

$>70$ students of each gender from the scientific colleges at Taibah University.

$>70$ students of each gender from the humanities colleges at Taibah University.

$>70$ students of each gender from the different health colleges at Taibah University

\section{Inclusion criteria:-}

The students of the different colleges (Scientific, humanities and health) at Taibah university in El-Madinah ElMunawarah

\section{Exclusion criteria:-}

1. Non Taibah University Students.

2. Students of Taibah University branches(outside El-Madinah El-Munawarah)

\section{Ethical clearance form:-}

1. Ethical clearance will be sought before the start of the study from the Taibah University College of Dentistry Research Ethics Committee (TUCD REC)

2. Data will be collected coded and locked in a password-protected computer at the principal investigator office to ensure confidentiality and privacy of patient data.

\section{Statistical Analysis:-}

For the statistical analysis, the data will be used for descriptive parameters in the form of frequency, percentage means and standard deviations. Chi-square and one-way ANOVA will be used to determine the significant differences in the frequency of subjects with other variables. Pearson Correlation will be used to correlate the variables using SPSS version $21^{3}$ to analyses the data. The level of significance was set at $\mathrm{p}<0.05$.or $\mathrm{p}<0.001$.

\section{Results:-}

Therewere484 respondents to the questionnaire from students of both genders from the various colleges at Taibah University

From the total of 484 respondents there were 139 (28.7\%) males and $345(71.3 \%)$ females (Table 1)

\footnotetext{
${ }^{1}$ http://www.raosoft.com/samplesize.html
}

2. www.ibm.com/software/analytics/spss/

${ }^{1}$ IBM SPSS Statistics IBM North America, 590 Madison Avenue, New York, NY 10022. United States, Email:www.ibm.com 
The age of the respondents ranged between 16-39 years of age. The respondents were grouped into 5 age groups. The 16-20 years formed (27.5\%) and the 21-25 years of the respondents formed the largest age group comprising of $57.9 \%$, the $26-30$ years age group formed $(10.8 \%)$, the $31-35$ years formed the smallest age groups consisting of (1.4\%). The $36-40$ years age group formed $(2.5 \%)$. (Table 1 )

The respondents came from three types of colleges, the Health and medical colleges, the Literary \& humanitarian colleges and the scientific colleges. From the Health and medical colleges there were $123(25.5 \%)$ respondents, while from the Literary \& humanitarian colleges were205 (42.5\%)respondents and from the Scientific colleges there were $154(31.9 \%)$ respondents(Table 1$)$

The respondents represented the various academic years, from the $1^{\text {st }}$ of college to the $6^{\text {th }}$ year of college. The first academic year students comprised of 46(10.6\%) of respondents were in, the $2^{\text {nd }}$ academic year were $91(20.9 \%)$, $63(14.4 \%)$ were in the $3^{\text {rd }}$ year, $79(18.1 \%)$ were in $4^{\text {th }}$ year, $43(9.9 \%)$ were in the $5^{\text {th }}$ year, and $114(26.1 \%)$ were in the $6^{\text {th }}$ year (Table 1)

The respondentswho have traveled outside Saudi Arabia comprised of 200(43.9\%), while the majority of the respondents 256(56.1\%) respondentshave not traveled outside Saudi Arabia (Table 2).

The majority of the respondents $245(53.6 \%)$ rated their health as excellent,166(36.3\%) rated their health as very good,39(8.5\%) rated their health as good, $4(0.9 \%)$ rated their health as acceptable,2(0.4\%) rated their health as poor, and $1(0.2 \%)$ rated their health as very poor (Table 2$)$

The majority of the respondents were not smokers, comprising of 381(83.2\%) while only $77(16.8 \%)$ were smokers (Table 2)

The majority of the respondents 442(97.4\%) have heard About HIV/AIDS, (Figure 1).

The majority of the respondentsheard of HIV/AIDS from the TV 291(60\%), this is followed by 278(57.4\%) respondentswho heard of HIV/AIDS from Internet,67(13.8\%) heard about HIV/AIDS from Public health officials, , 212(43.8\%) have heard about HIV/AIDS from their studying, while 137(28.3\%) heard about HIV/AIDS from Magazines \& Newspapers , 63(13\%) have heard about HIV/AIDS from the radio and 4(0.8) have heard about HIV/AIDS from Friends. Table (3)

When asked about the symptoms of HIV/AIDS, the majority of the respondents $189(39 \%)$ think that persistent fever is a of the symptoms of HIV, 173(35.7\%) think loss of weight and appetite is one of the symptoms of HIV, $99(20.5 \%)$ think acute diarrhea is one of the symptoms of HIV and 199(41.1\%) of them don't Know.Table (4)

When asked about the organisms that causes HIV/AIDS, the majority of the respondents $279(57.6 \%)$ think it's avirus is the causative organism of HIV , 11(2.3\%) think it's bacteria, 9(1.9\%) think it's a fungi , 4(0.8\%) think it's a parasite and 181(37.4\%) don't know. (Table 5)

When asked have heard of a condom, most of the respondents $401(82.9 \%)$ claimed to have heard of Condoms (Table 5) When asked that a Condom is a way to prevent the spread of AIDS87(18\%) of the respondents totally agree $109(22.5 \%)$ only agree with that, $83(17.1 \%)$ neither agree nor disagree, $28(5.8 \%)$ disagreed and $177(36.6 \%)$ don't know. (Table6)

When the respondents were asked if their knowledge of AIDS is far better when they entered the college or university" 62(12.8\%) totally agree $132(27.3 \%$ ) agree, $206(42.6 \%$ ) disagree and $84(17.4 \%)$ said that they totally disagree (Table7).

When asked to what extent you wish to obtain additional information and education about the basic information about AIDS, 47(9.7\%) of the respondents think that there is no need for them to get more knowledge, 214 (44.2\%) think that there is some need, $126(26 \%)$ think that there is only a slight need and $97(20 \%)$ think that there is a great need. (Table 7) 
When asked if they think their knowledge is sufficient 23(4.8\%) of the respondents believe strongly that their knowledge about HIV is sufficient, $89(18.4 \%)$ thinks it's enough, 192(39.7\%) don't think it's enough, 77(15.9\%) don't think strongly it's enough and 103(21.3\%) answer with I don't know. (Table8)

In answer to the question “does the term HIV means the term AIDS, the vast majority $308(63.6 \%)$ don't know, $126(26 \%)$ of the respondents think that it does, and 50(10.3\%) don't think so. (Table 9).

When asked if there is a cure for AIDSthe majority 272(56.2\%) think there is no cure for AIDS, 43(8.9\%) of the respondents think there is and 169(34.9\%) said they don't know. (Table 9)

In response a question whether coughing and/or sneezing transmit HIV/AIDS, the majority 215(44.4\%) answered I don't know, 200(41.3\%) of the respondentssaid no, while 69(14.3\%) said yes, (Table 9).

In response a question that pregnant women with AIDS give birth to infected child, the majority 230(47.5\%) don't know, 191(39.5\%) said yes while only 63(13\%) said no. (Table 9)

When asked if with AIDS / HIV (AIDS) look and feel healthy, the bulk of the respondents 248(51.2\%) did not think so, $189(39 \%)$ did not know and $47(9.7 \%)$ of the respondentssaid yes (Table9)

In response to a question can infected with HIV could show no signs or symptoms for a period of five years or more, the majority $228(47.1 \%)$ of respondents don't agree, 225(46.5\%) don't know while 31(6.4\%) of the respondents think that the person who is infected with HIV could show no signs or symptoms for a period of five years or more, with that and. (Table 9)

Is there a vaccine to immunize adults from AIDS, the majority 291(60.1\%)don't know,152(31.4\%) think there is no vaccine and $41(8.5 \%)$ of the respondents think that there is a vaccine against HIV (Table 10)

In response to a question do you think that people with AIDS can live with their families without the spread of AIDS? 182(37.6\%) don't know, 169(34.9\%) of the respondentsbelieve that the people with AIDS can live with their families without spreading AIDS, and 133(27.5\%) think they can't live with their families without spreading AIDS (Table 10)

In response to a question do you think that people with AIDS can continue their education and mingle with their colleagues in schools and universities? The majority 258(53.3\%) of the respondents think that people with AIDS can continue their education and mingle with their colleagues while 226(46.7\%) think they couldnot (Table10)

The was majority 410(84.7\%) haven't been checked for HIV/AIDS while 74(15.3\%) of the respondents have been checked for HIV (Table 10) 
Table 1:- Personal information

\begin{tabular}{|c|c|c|}
\hline Gender & Frequency & \% \\
\hline Female & 345 & 28.7 \\
\hline Male & 139 & 27.5 \\
\hline Age group & 122 & 57.9 \\
\hline $16-20$ & 257 & 10.8 \\
\hline $21-25$ & 48 & 1.4 \\
\hline $26-30$ & 6 & 2.5 \\
\hline $31-35$ & 11 & \\
\hline $36-40$ & & 25.4 \\
\hline Type of College & 123 & 42.4 \\
\hline Health and medical colleges & 205 & 31.8 \\
\hline Literary $\&$ hamitarian colleges & 154 & \\
\hline Academic Year & & \\
\hline 1 & 46 & 10.6 \\
\hline 2 & 91 & 20.9 \\
\hline 3 & 63 & 14.4 \\
\hline 4 & 79 & 18.1 \\
\hline 5 & 43 & 9.9 \\
\hline 6 & 114 & 26.1 \\
\hline
\end{tabular}

Table 2:- Health Related information

\begin{tabular}{|c|c|c|}
\hline Travelled outside KSA & Frequency & $\%$ \\
\hline Yes & 200 & 43.9 \\
\hline No & 256 & 56.1 \\
\hline Rate your health & & 53.6 \\
\hline Excellent & 245 & 36.3 \\
\hline Very good & 166 & 8.5 \\
\hline Good & 39 & 0.9 \\
\hline Acceptable & 4 & 0.4 \\
\hline Poor & 2 & 0.2 \\
\hline Very poor & 1 & \\
\hline Do you smoke & & \\
\hline Yes & 77 & \\
\hline No & 381 & \\
\hline
\end{tabular}

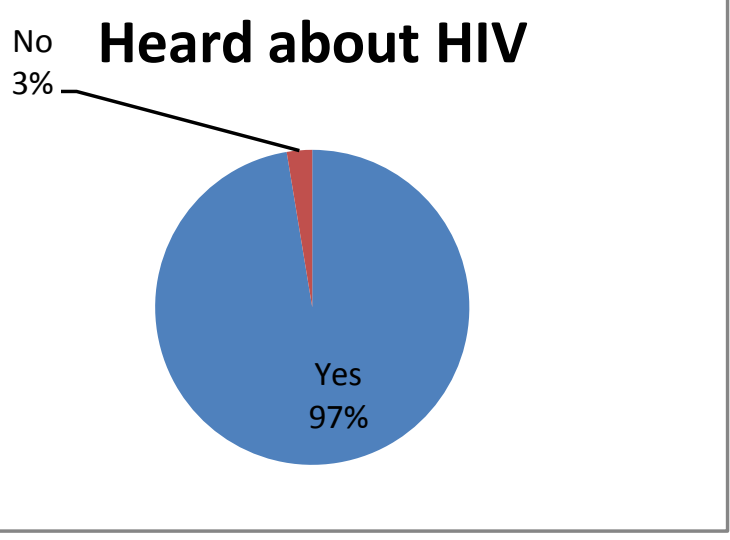

Figure 1:- Heard about HIV 
Table 3:- The way respondents heard about HIV

\begin{tabular}{|l|l|l|l|l|}
\hline \multirow{2}{*}{ How did you hear about AIDS } & Yes & No & \% \\
\cline { 2 - 5 } & N & \% & N & 42.6 \\
\hline Internet & 278 & 57.4 & 206 & 86.2 \\
\hline Public health official & 67 & 13.8 & 417 & 39.9 \\
\hline TV & 291 & 60.1 & 193 & 56.2 \\
\hline Studying & 212 & 43.8 & 272 & 71.7 \\
\hline Newspapers and magazines & 137 & 28.3 & 347 & 87 \\
\hline Radio & 63 & 13 & 421 & 99.2 \\
\hline Friends & 4 & 0.8 & 480 & \\
\hline
\end{tabular}

Table4:- Symptoms of AIDS.

\begin{tabular}{|l|l|l|l|l|}
\hline What are the symptoms of & Yes & No \\
\cline { 2 - 5 } AIDS? & N & \% & N & \% \\
\hline Persistent fever & 189 & 39.0 & 295 & 61.0 \\
\hline loss of weight and apatite & 173 & 35.7 & 311 & 64.3 \\
\hline Acute diarrhea & 99 & 20.5 & 385 & 79.5 \\
\hline I don't know & 199 & 41.3 & 275 & 57.1 \\
\hline
\end{tabular}

Table 5:-Cause of AIDS

\begin{tabular}{|l|l|l|}
\hline Cause of AIDS & Frequency & $\%$ \\
\hline virus & 279 & 57.6 \\
\hline bacteria & 11 & 2.3 \\
\hline Fungi & 9 & 1.9 \\
\hline parasites & 4 & 0.8 \\
\hline I don't know & 181 & 37.4 \\
\hline
\end{tabular}

Table 6:- Condoms info.

Heard about condom.

\begin{tabular}{|l|l|l|}
\hline Yes & 401 & 82.9 \\
\hline No & 83 & 17.1 \\
\hline Condoms prevent AIDS & & \\
\hline Totally agree & 87 & 18 \\
\hline Agree & 109 & 22.5 \\
\hline Neither agree nor disagree & 83 & 17.1 \\
\hline Disagree & 28 & 5.8 \\
\hline I don't know & 177 & 36.6 \\
\hline
\end{tabular}


Table 7:- Need for more information about AIDS

\begin{tabular}{|l|l|l|}
\hline Need for basic information about AIDS? & Frequency & $\%$ \\
\hline No need & 47 & 9.7 \\
\hline Some need & 214 & 44.2 \\
\hline Slight need & 126 & 26.0 \\
\hline Great need & 97 & 20.0 \\
\hline
\end{tabular}

Table 8:-Amount of respondent's information about AIDS.

\begin{tabular}{|c|l|l|}
\hline $\begin{array}{c}\text { Do you think that your knowledge about AIDS is } \\
\text { sufficient? }\end{array}$ & Frequency & $\%$ \\
\hline I believe strongly & 23 & 4.8 \\
\hline I think it's enough & 89 & 18.4 \\
\hline I don't know & 103 & 21.3 \\
\hline I don't think it's enough & 192 & 39.7 \\
\hline I strongly don't think it's enough & 77 & 15.9 \\
\hline
\end{tabular}

Table 9:-AIDS Knowledge.

\begin{tabular}{|c|c|c|c|c|c|c|}
\hline $\begin{array}{l}\text { Term HIV } \\
\text { means the } \\
\text { term AIDS? }\end{array}$ & Frequency & $\%$ & $\begin{array}{l}\text { Is there a } \\
\text { cure for } \\
\text { AIDS? }\end{array}$ & Frequency & & $\%$ \\
\hline Yes & 126 & 26 & Yes & 43 & 8.9 & \\
\hline No & 50 & 10.3 & No & 272 & 56.2 & \\
\hline Idon't know & 308 & 63.6 & I don't know & 169 & 34.9 & \\
\hline $\begin{array}{l}\text { Transition } \\
\text { of HIV } \\
\text { could be } \\
\text { through } \\
\text { coughing? }\end{array}$ & & & $\begin{array}{l}\text { Pregnant } \\
\text { women with } \\
\text { AIDS will } \\
\text { have } \\
\text { children with } \\
\text { AIDS? }\end{array}$ & & & \\
\hline yes & 69 & 14.3 & yes & 191 & 39.5 & \\
\hline No & 200 & 41.3 & No & 63 & 13 & \\
\hline Idon't know & 215 & 44.4 & I don't know & 230 & 47.5 & \\
\hline $\begin{array}{l}\text { Are those } \\
\text { infected } \\
\text { with AIDS } \\
\text { look and } \\
\text { feel } \\
\text { healthy? }\end{array}$ & Frequency & $\%$ & $\begin{array}{l}\text { Can } \\
\text { someone } \\
\text { infect with } \\
\text { AIDS show } \\
\text { no signs for } \\
\text { a period of } 5 \\
\text { years or } \\
\text { more? }\end{array}$ & Frequency & $\%$ & \\
\hline Yes & 47 & 9.7 & yes & 31 & 6.4 & \\
\hline No & 248 & 51.2 & No & 228 & 47.1 & \\
\hline Idon't know & 189 & 39 & I don't know & 225 & 46.5 & \\
\hline
\end{tabular}

Table 10:- AIDS Attitude

\begin{tabular}{|l|l|l|l|l|l|}
\hline $\begin{array}{l}\text { Is there a } \\
\text { vaccine } \\
\text { against } \\
\text { AIDS? }\end{array}$ & Frequency & $\%$ & $\begin{array}{l}\text { people with } \\
\text { AIDS can live } \\
\text { with their } \\
\text { familieswithout } \\
\text { the spread of } \\
\text { AIDS? }\end{array}$ & Frequency & $\%$ \\
\hline Yes & 41 & Yes & 169 & 34.9 \\
\hline No don't & 291 & 8.5 & No & 133 & 27.5 \\
\hline I & 31.4 & I don't know & 182 & 37.6 \\
\hline
\end{tabular}




\begin{tabular}{|l|l|l|l|l|l|}
\hline know & & & & \\
\hline $\begin{array}{l}\text { people with } \\
\text { AIDS can } \\
\text { continue } \\
\text { their } \\
\text { education } \\
\text { and mingle } \\
\text { with their } \\
\text { colleagues }\end{array}$ & & $\%$ & $\begin{array}{l}\text { Checked for } \\
\text { AIDS before }\end{array}$ & Frequency & $\%$ \\
\hline Yes & 258 & 53.3 & yes & 74 & \\
\hline No & 226 & 46.7 & No & 410 & \\
\hline
\end{tabular}

\section{Discussion}

This is the first study on Knowledge, Attitude and Practice of HIV/AIDS in students at Taibah University in Medina, Saudi Arabia, This study reports an average level of knowledge relating to HIV/AIDS among students of Taibah University.

The majority of the respondents were female (71\%), similar findings have also been reported in similar study done in South Africa. [6]

Almost All respondents had heard about HIV/AIDS (97\%), similar findings have also been reported in study done in Lao People's Democratic Republic. [7]

Only $10 \%$ of the respondents differentiate between HIV and AIDS, This is lower than similar study $81.9 \%$ done in Ethiopia. [8]

Majority of respondents $272(56.2 \%)$ knew there is no cure for AIDS and 169 (34.9\%) said they don't know, While in a similar study done in Ethiopia $90.3 \%$ of respondents knew there is no cure for AIDS.[8]

Most of the students knew that the use of condoms during sexual intercourse could prevent HIV, Similar findings have also been reported in study done in Lao People's Democratic Republic. [8]

The majority of the respondents heard of HIV/AIDS from the TV 291(60\%), this is followed by 278 (57.4\%) respondents who heard of HIV/AIDS from Internet, 67(13.8\%) heard about HIV/AIDS from Public health officials, , $212(43.8 \%)$ have heard about HIV/AIDS from their studying, while 137 (28.3\%) heard about HIV/AIDS from Magazines \& Newspapers , 63(13\%) have heard about HIV/AIDS from the radio and $4(0.8)$ have heard about HIV/AIDS from Friends, While in a different study conducted in Lao People's Democratic Republic their findings were $(61.3 \%)$ source of information was the television, followed by the radio (25.3\%). Less than one-fifth of the respondents were aware about HIV/AIDS from friends (7.7\%), brochures (3.7\%), newspapers (1.3\%) and magazines $(0.7 \%) .[8]$

\section{Limitations:-}

Because of the restricted cultures here in Saudi Arabia, it was difficult to ask the participants about their sex activates and related question to that. Also because of that most of the student will not respond to sex related questions. However, the anonymity of the questionnaires hopefully encouraged students to be honest in their responses.

\section{Conclusion:-}

In conclusion, the surveyed university students had an average KAPs about HIV/AIDS. The students need more information about AIDS symptoms, transmition and how to prevent its infection. It is recommended to start HIV/AIDS Prevention Programs at Taibah University giving attention to changing attitudes and practices among students. The study reveals that most of student get their information from the TV, so there should be more TV programs about AIDS. 


\section{Recommendations:-}

It is recommended to start HIV/AIDS Prevention Programs at Taibah University giving attention to changing attitudes and practices among students.

\section{Acknowledgments:}

We thank the respondents for their cooperation to answer and complete the survey and specialthanks to Dr. Abdulrahman Ramadan for his effort to help me with every step.

\section{References:-}

1. Addis Z, Yalew A, Shiferaw Y etal. Knowledge, attitude and practice towards voluntary counseling and testing among university students in Northwest Ethiopia: a cross sectional study. BMC Public Health. 2013; 13(714): $2-8$.

2. Shiferaw Y, Alemu A, GirmaA et al. Assessment of knowledge, attitude and risk behaviors towards HIV/AIDs and other sexual transmitted infections among preparatory students of Gondar town, northwest Ethiopia. BMC Research Notes. 2011; 4(505):2-8.

3. UNAIDS (2010)' UNAIDS report on the global AIDS epidemic.

4. Joint United Nations Programme on HIV/AIDS (UNAIDS) and World Health Organization (WHO)AIDS epidemic update: December 2002 WHO. 2002. pp. 1-40.

5. M Davhana-Maselesele, D(Phil), LL Lalendle, UshotanefeUseh Knowledge, attitudes and practices related to HIV/AIDS/AIDS among learners in Vhembe district of Limpopo Province by 2007.

6. M.A. Pogrel. Removal of Third Molars. BAGHERI SC, Bell RB, KHAN HA, editors. Current Therapy in Oral and Maxillofacial Surgery, 1st Edition. Saunders: Elsevier Inc; 2011. P. 129-130.

7. Basini, Dixie Thomas. ASSESSMENT OF KNOWLEDGE, ATTITUDES AND PRACTICES (KAP) ON HIV/AIDS AMONG PEER EDUCATORS AND STUDENTS AT THE TSHWANE UNIVERSITY OF TECHNOLOGY: a cross sectional study. Thesis (MPhil)--Stellenbosch University. (2013-03)

8. Bounbouly Thanavanh, Md. Harun-Or-Rashid, Hideki Kasuya and Junichi Sakamoto. Knowledge, attitudes and practices regarding HIV/AIDS among male high school students in Lao People's Democratic Republic. : A cross sectional study. Journal of the International AIDS Society 2013, 16:17387

9. WondemagegnMulu ,BayehAbera, MulatYimer. Knowledge, attitude and practices on HIV/AIDS among students of Bahir Dar University: a cross sectional study. Science Journal of Public Health. 2014; 2(2): 78-86 